\title{
Prevalence and factors associated with diagnosis of early rheumatoid arthritis in the south of Brazil
}

\author{
Rafael Kmiliauskis Santos Gomes ${ }^{1,2,4^{*}}$, Ana Carolina de Linhares ${ }^{3}$ and Lucas Selistre Lersch ${ }^{3}$
}

\begin{abstract}
Background: Rheumatoid arthritis (RA) is an autoimmune inflammatory disease characterized by peripheral and symmetrical polyarthritis. It can be divided into Very Early Rheumatoid Arthritis (VERA) diagnosed up to 3 months of symptoms and late onset (Late Early Rheumatoid Arthritis - LERA), diagnosed between 3 and 12 months. Currently, it is recommended to evaluate the patient with joint symptoms as early as possible, and the first 12 weeks of manifestations represent the ideal phase for the diagnosis, favoring a better evolution of the treatment. The present study aimed to determine the prevalence of early diagnosis of rheumatoid arthritis, mean time of diagnosis and to determine possible associated factors in the municipality of Blumenau, Santa Catarina, Brazil.

Methods: A cross-sectional study using the 1987 American College of Rheumatology diagnostic criteria to select patients attended at primary or secondary health care units in Blumenau, Santa Catarina, southern Brazil, in 2014. Diagnostic time was verified by self-report of the time elapsed between the onset of symptoms and the diagnosis made by a rheumatologist. To test the associations, the chi-square test, the Wald linear trend test and the Poisson regression analysis were used.
\end{abstract}

Results: The mean time of diagnosis was 28 months. The prevalence of diagnosis up to 3 and 12 months was 27. $7 \%$ and $64.8 \%$, respectively. Obesity was associated with time diagnosis in both periods. The $0-4$ years category of the variable education was associated only with the period up to 12 months.

Conclusion: The mean time of diagnosis was similar to the national context. Among socioeconomic factors, lower education was associated with the diagnosis of late onset RA. The anthropometric variable presented a progressive increase in the prevalence due to the longer time to diagnosis.

Keywords: Rheumatoid arthritis, Prevalence, Diagnosis, Epidemiology

\section{Background}

Rheumatoid arthritis (RA) is an inflammatory autoimmune disease characterized by peripheral and symmetric polyarthritis [1]. It can be divided into Very Early Rheumatoid Arthritis (VERA) diagnosed up to 3 months of symptoms and late onset (Late Early Rheumatoid Arthritis - LERA), diagnosed between 3 and 12 months [2]. It is estimated that the disease affects between 0.5 and $1 \%$ of the adult world population. Its complications can lead to deformity and destruction of joints, due to

\footnotetext{
* Correspondence: gomesmed2002@ibest.com.br

${ }^{1}$ Specialty Center of the City of Blumenau, Blumenau, Santa Catarina State (SC), Brazil

${ }^{2}$ Specialty Center of the City of Brusque, Brusque, SC, Brazil

Full list of author information is available at the end of the article
}

the erosion of bone and cartilage [3]. These complications can cause severe joint damage with loss of functional capacity, so the importance of early diagnosis and immediate treatment [4].

Currently, it is recommended to evaluate a patient with joint symptoms as early as possible, since the critical period of the first 12 weeks of manifestations represents the ideal phase for the diagnosis, favoring a better evolution of the treatment $[5,6]$. . Despite this, the world reality differs from that recommended. In Saudi Arabia, an average time of approximately 30 months was verified [7], whereas in England, the ERAN study found a period of approximately 4 months for the diagnosis [8]. In Brazil, a study from São Paulo verified that the average

(C) The Author(s). 2018 Open Access This article is distributed under the terms of the Creative Commons Attribution 4.0 International License (http://creativecommons.org/licenses/by/4.0/), which permits unrestricted use, distribution, and 
waiting time between the beginning of the symptoms and rheumatologic evaluation was on average 39 months:[9] This situation could be modified with early referral to the specialist and immediate diagnosis of the disease [10].

A Canadian study showed that younger, higher socioeconomic level and female subjects consulted more quickly with specialists, so they were diagnosed earlier [11]. Another study, conducted in Venezuela, showed a significant difference in diagnosis time between private and public health centers. This demonstrates that several factors influence the establishment of the diagnostic interval and initiation of therapy in patients with RA [12].

The prognostic consequences of diagnostic delay may be irreversible, such as deformities and functional limitation by persistent inflammation and progressive joint damage [13]. One can also cite the presence of work incapacity [9] and for daily tasks [14]. Another consequence would be the greater refractoriness of conventional synthetic disease-modifying antirheumatic drugs (csDMARD), leading to an increased risk of immunobiological use, depending on the severity and progression of the disease [15]. This would increase the costs of drug treatment, mainly affecting the Unified Health System (SUS) [16].

The present study aimed to determine the prevalence of early diagnosis of rheumatoid arthritis, the mean time of diagnosis and to determine possible associated factors in the city of Blumenau, Santa Catarina, Brazil.

\section{Methods}

This cross-sectional, population-based study was conducted between July 2014 and January 2015 with individuals 20 years of age or older with rheumatoid arthritis according to the American College of Rheumatology criteria of 1987, of both sexes, resident in the municipality of Blumenau, southern region of Brazil.

The formula for calculating the sample size required to estimate the prevalence of an event in a simple random sample was used considering the following parameters: $0.5 \%$ RA prevalence (1110 patients), 50\% prevalence of exposure and unknown outcome, $5 \%$ sample error and $95 \%$ confidence level. The participants were recruited from all primary care centers (Unidades Básicas de Saúde - UBS), the specialty outpatient clinic and the specialty pharmacy of the municipality. Sample loss occurred when households were visited twice, once on the weekend and again in the evening, and no resident was at home, the resident had moved or refused to participate in the study on both occasions. The data collection team consisted of a local supervisor docente and 8 medical academics of the Regional University of Blumenau (Universidade Regional de Blumenau - FURB) previously trained to conduct structured interviews at home and, if necessary, by telephone. Quality control was performed in $20 \%$ of respondents, who were interviewed for the second time using a short questionnaire.

The dependent variable was the diagnostic time of rheumatoid arthritis analyzed in two periods: up to 3 months and 12 months. The independent variables were defined as: a) demographic factors: sex, age in completed years, ranging from 20 to $39,40-49$ for adults and $\geq 60$ years for the erderly b) socioeconomic factors: education in years of completed study, divided into $0-4,5-8$ and $\geq 9$ years, current monthly personal income in minimum wages before diagnosis of the disease categorized in the first tertile (lowest), second tertile and third tertile (highest); c) anthropometric factors: body mass index (BMI $\left.-\mathrm{kg} / \mathrm{m}^{2}\right)$ subdivided according to the World Health Organization (WHO) in $\leq 24.9$ for ideal weight, between 25 and 29.9 for overweight and $\geq 30$ for obesity; d) disease-related factors: total disease time in months diagnosed by the rheumatologist, categorized between 0 and 24 months and $>24$ months of disease, type of medical care in the last 12 months, classified in three groups, the Unified Health System (Sistema Único de Saúde - SUS; free, public healthcare system), Public-Private Healthcare (supplementary healthcare system), and the private healthcare (fee-for-service care) defined according to the Ministry of Health (Ministério da Saúde - MS), number of consultations with rheumatologist in the last 12 months, categorized between 0 and 2 and $\geq 3$ consultations, current use of cs DMARD, current use of biological disease-modifying antirheumatic drugs (bDMARD) - tumor necrosis factor inhibitors / TNFi (adalimumab, etanercept, infliximab), HAQ (Health Assessment Questionnaire), ranging from 0 to 1 (mild impairment), 1.1 to 2 (moderate) and 2.1 to 3 (severe), the presence of bone erosions in the radiography of hands; and e) labor factor: current professional situation (working, health insurance, disability retirement, retirement for time of service).

The data was entered in a system developed for this study with output in the format of the excel table and later the final file was exported to Stata 10.0 program (Stata Corp., College Station, USA). The variables of interest were analyzed for their distributions using average, standard deviation, median for continuous variables; and frequency and percentage for the categorical ones.

To test the association between symptom time and diagnosis of rheumatoid arthritis in months with independent variables, the chi-square test and, where appropriate, Wald's linear trend test were used. Then, the Poisson regression analysis was performed to verify the association of the factors studied with the dependent variable, estimating the crude and adjusted prevalence ratios (PR), the respective 95\% confidence intervals and the value of $\mathrm{p}$. 
Table 1 Description of the sample and the prevalence of the diagnostic time of up to 3 and 12 months of symptons according to the independente variables in patients with rheumatoid arthritis of Blumenau, Santa Catarina, Brazil, 2014

\begin{tabular}{|c|c|c|c|c|c|c|c|c|}
\hline \multirow[t]{2}{*}{ Variables } & \multicolumn{2}{|c|}{ Sample } & \multicolumn{3}{|c|}{ Diagnostic up to 3 months } & \multicolumn{3}{|c|}{ Diagnostic up to 12 months } \\
\hline & $N$ & $\%$ & Prevalence(\%) & $\mathrm{Cl} 95 \%$ & $p$ & Prevalence(\%) & $\mathrm{Cl} 95 \%$ & $p$ \\
\hline Total & 296 & 100,0 & $27,7 \%$ & $(22,5-32,8)$ & & $64,8 \%$ & $(59,3-70,3)$ & \\
\hline $\operatorname{Sex}(n=296)$ & & & & & $0,098^{\mathrm{a}}$ & & & $0,708^{a}$ \\
\hline Male & 48 & 16,2 & 37,5 & $(23,2-51,7)$ & & 62,5 & $(48,2-76,7)$ & \\
\hline Female & 248 & 83,8 & 25,8 & $(20,3-31,2)$ & & 65,3 & $(59,3-71,2)$ & \\
\hline Age in years $(n=287)$ & & & & & $0,227^{b}$ & & & $0,893^{b}$ \\
\hline $20-39$ & 16 & 5,6 & 12,5 & $(5,7-30,7)$ & & 62,5 & $(35,8-89,1)$ & \\
\hline $40-59$ & 146 & 50,9 & 26,7 & $(19,4-33,9)$ & & 65,7 & $(57,9-73,5)$ & \\
\hline$\geq 60$ & 125 & 43,5 & 29,6 & $(21,5-37,7)$ & & 64,1 & $(55,4-72,5)$ & \\
\hline Education in completed years $(n=284)$ & & & & & $0,447^{b}$ & & & $0,093^{b}$ \\
\hline $0-4$ & 106 & 37,3 & 27,4 & $(18,6-36,2)$ & & 70,5 & $(61,5-79,5)$ & \\
\hline $5-8$ & 76 & 26,7 & 21,1 & $(11,6-30,4)$ & & 64,4 & $(53,4-75,4)$ & \\
\hline$>9$ & 102 & 35,9 & 32,1 & $(23,1-41,1)$ & & 59,4 & $(49,9-68,9)$ & \\
\hline \multicolumn{5}{|c|}{ Current monthly personal income in minimum wages $(n=248)$} & $0,799^{b}$ & & & $0,493^{b}$ \\
\hline Third tertile (higher) & 82 & 33,1 & 28,5 & $(18,7-38,4)$ & & 59,5 & $(48,8-70,2)$ & \\
\hline Second tertile & 82 & 33,1 & 25,6 & $(15,9-35,2)$ & & 65,8 & $(55,3-76,3)$ & \\
\hline First tertile (lower) & 84 & 33,8 & 26,8 & $(17,1-36,6)$ & & 64,6 & $(54,1-75,2)$ & \\
\hline Body mass index $\left(\mathrm{Kg} / \mathrm{m}^{2}\right)(n=285)$ & & & & & $0,012^{b}$ & & & $0,001^{b}$ \\
\hline$\leq 24,9$ & 110 & 38,6 & 36,3 & $(27,2-45,4)$ & & 75,4 & $(67,2-83,6)$ & \\
\hline $25-29,9$ & 113 & 39,7 & 24,7 & $(16,7-32,8)$ & & 61,9 & $(52,8-71,1)$ & \\
\hline$\geq 30$ & 62 & 21,7 & 19,3 & $(9,2-29,3)$ & & 51,6 & $(38,8-64,4)$ & \\
\hline \multicolumn{5}{|c|}{ Type of service in the last 12 months $(n=269)$} & $0,166^{b}$ & & & $0,515^{b}$ \\
\hline Public healthcare system & 113 & 42,1 & 23,8 & $(15,9-31,8)$ & & 64,6 & $(55,7-73,4)$ & \\
\hline Supplementary healthcare system & 84 & 31,2 & 27,3 & $(17,7-37,1)$ & & 65,4 & $(55,2-75,7)$ & \\
\hline Fee-for-service care & 72 & 26,7 & 33,3 & $(22,3-44,3)$ & & 69,9 & $(58,6-80,2)$ & \\
\hline \multicolumn{5}{|c|}{ Total number of consultations with a rheumatologist in the last 12 months $(n=281)$} & $0,165^{b}$ & & & $0,069^{b}$ \\
\hline $0-1$ & 42 & 15,0 & 33,3 & $(18,4-48,2)$ & & 69,1 & $(54,4-83,6)$ & \\
\hline $2-3$ & 126 & 44,9 & 23,0 & $(15,5-30,4)$ & & 58,7 & $(50,0-67,4)$ & \\
\hline$\geq 4$ & 113 & 40,1 & 30,9 & $(22,3-39,6)$ & & 69,9 & $(61,3-78,4)$ & \\
\hline Disease time in months $(n=235)$ & & & & & $0,193^{\mathrm{a}}$ & & & $0,102^{2}$ \\
\hline $0-24$ & 37 & 15,7 & 37,8 & $(21,4-54,2)$ & & 75,6 & $(61,1-90,1)$ & \\
\hline$>24$ & 198 & 84,3 & 27,2 & $(21,1-33,5)$ & & 61,6 & $(54,7-68,4)$ & \\
\hline Use of cs DMARD $(n=296)$ & & & & & $0,396^{\mathrm{a}}$ & & & $0,994^{\circ}$ \\
\hline Yes & 202 & 68,2 & 29,2 & $(22,8-35,5)$ & & 64,8 & $(58,2-71,4)$ & \\
\hline No & 94 & 31,7 & 24,4 & $(15,6-33,3)$ & & 64,8 & $(55,1-74,7)$ & \\
\hline Use of TNFi (ADA + ETA+IFX) $(n=288)$ & & & & & $0,960^{\mathrm{a}}$ & & & $0,592^{2}$ \\
\hline Yes & 75 & 26,1 & 28,0 & $(17,5-38,4)$ & & 61,3 & $(50,1-72,6)$ & \\
\hline No & 213 & 73,9 & 27,6 & $(21,6-33,7)$ & & 64,7 & $(58,3-71,2)$ & \\
\hline $\mathrm{HAQ}(n=165)$ & & & & & $0,904^{b}$ & & & $0,211^{b}$ \\
\hline $0-1$ (mild) & 65 & 39,4 & 24,6 & $(13,8-35,3)$ & & 55,3 & $(42,9-67,7)$ & \\
\hline 1,1-2 (moderate) & 59 & 35,7 & 32,2 & $(19,9-44,4)$ & & 69,4 & $(57,3-81,5)$ & \\
\hline 2,1-3 (severe) & 41 & 24,9 & 24,3 & $(10,6-38,1)$ & & 65,8 & $(50,7-81,0)$ & \\
\hline
\end{tabular}


Table 1 Description of the sample and the prevalence of the diagnostic time of up to 3 and 12 months of symptons according to the independente variables in patients with rheumatoid arthritis of Blumenau, Santa Catarina, Brazil, 2014 (Continued)

\begin{tabular}{|c|c|c|c|c|c|c|c|c|}
\hline \multirow[t]{2}{*}{ Variables } & \multicolumn{2}{|c|}{ Sample } & \multicolumn{3}{|c|}{ Diagnostic up to 3 months } & \multicolumn{3}{|c|}{ Diagnostic up to 12 months } \\
\hline & N & $\%$ & Prevalence(\%) & $\mathrm{Cl} 95 \%$ & $p$ & Prevalence(\%) & $\mathrm{Cl} 95 \%$ & $p$ \\
\hline \multicolumn{5}{|c|}{ Presence of radiological changes (erosions) in hands $(n=237)$} & $0,814^{\mathrm{a}}$ & & & $0,665^{\mathrm{a}}$ \\
\hline No & 89 & 37,5 & 26,9 & $(17,5-36,3)$ & & 66,2 & $(56,2-76,3)$ & \\
\hline Yes & 148 & 62,5 & 28,3 & $(21,1-35,7)$ & & 63,5 & $(55,6-71,3)$ & \\
\hline Current professional situation (237) & & & & & $0,325^{b}$ & & & $0,132^{b}$ \\
\hline Working & 77 & 32,5 & 23,3 & $(13,7-33,1)$ & & 59,7 & $(48,5-70,9)$ & \\
\hline Health insurance & 29 & 12,2 & 24,1 & $(7,5-40,7)$ & & 55,1 & $(35,9-74,4)$ & \\
\hline Disability retirement & 65 & 27,5 & 27,6 & $(16,5-38,8)$ & & 60,1 & $(47,7-77,2)$ & \\
\hline Retirement for time of service & 66 & 27,8 & 30,3 & $(18,9-41,6)$ & & 72,2 & $(61,9-83,7)$ & \\
\hline
\end{tabular}

csDMARD conventional synthetic disease-modifying antirheumatic drugs, TNFi tumor necrosis factor inhibitors ADA adalimumab, ETA etanercept, IFX infliximab, HAQ health assessment questionnaire; Cl 95\%: confidence interval of 95\%

${ }^{a}$ Chi-square test ${ }^{b}$ Wald's linear trend test

For the input in the final model, all the variables that presented a value of $p<0.20$ in the crude analysis were taken into account. The regression model adjusted for those variables that maintained the value of $p \leq 0.05$ or adjusted the final model. For the inclusion of the variables in the regression model, the researchers chose sequentially to include the variables: demographic, socioeconomic, anthropometric, related to the disease and professional situation.

This research was submitted to the research ethics committee of the University of São Paulo (USP) and FURB (protocol $n^{\circ} .339 / 13$ and 133/12, respectively) and approved; all participants signed the informed consent form.

\section{Results}

A total of 336 patients were identified. After excluding deceased patients and those who refused to participate in the study or patients without data for any variable, 296 patients were included in the study.

The majority of the sample consisted of females (83.8\%) and adults (50.9\%) with mean age and standard deviation (SD) of 58.1 years (SD: 11.5), ranging from 27 to 89 years. Regarding education, the majority of patients had 0 to 4 years of completed study (37.3\%), with a mean of 7.7 years (SD: 4.4). Regarding the disease-related characteristics, the mean disease duration was 126 months (SD: 100), ranging from 0 to 420 , mean HAQ of 1.3 (SD: 0.8) and that the majority of the population was using cs DMARD (68.2\%). The majority of individuals presented overweight BMI, mean of $26.6 \mathrm{~kg} / \mathrm{m}^{2}$ (SD: 4.9).

Regarding the factors related to the diagnosis time, it was observed that the sex variable, for diagnosis up to 3 months, prevailed among males; for diagnosis up to 12 months in the female sex. In relation to age, for diagnosis up to 3 months, preponderated in the population of 60 years or more; and for 12 months, from 40 to 59 years. Regarding education, individuals with more than 9 years of study predominated, for diagnosis up to 3 months; for diagnosis up to 12 months, the population with 0 to 4 years of study. Patients with a diagnosis established up to 3 months had income in the third tertile (highest), and for 12 months in the second tertile (intermediate). Regarding the variables related to the disease, it was observed that individuals who had a disease time of less than 24 months had a higher prevalence of early diagnosis for both periods. In addition, there was a progressive increase in the prevalence of obese individuals over time. Regarding the total number of consultations with rheumatologists in the last 12 months, the majority of patients diagnosed up to 3 months had 0 to 1 consultation, and those diagnosed up to 12 months, consumed a greater number of consultations, 4 or more (Table 1 ).

It was verified in the crude regression analysis that the dependent variable up to 3 months showed a tendency of association with sex and age, whereas education only for up to 12 months. Regarding the anthropometric variable, it was observed that in the two time intervals analyzed, the BMI was associated with the category of values $\geq 30$, since the longer the diagnosis, the greater the prevalence of obese individuals. The care performed by the SUS showed an associative tendency of lower prevalence with diagnosis in the very early period of the disease in relation to the private care. Patients diagnosed in both periods used fewer consultations than the reference category ( 2 to 3 visits in 12 months). Regarding the current professional situation, among the patients diagnosed up to 12 months, there was a trend of increasing form $11 \%$ to $34 \%$ in the health insurance in relation to the patients who remained working. Of the individuals diagnosed for up to 3 months, $16 \%$ had a prevalence of disease time greater than 24 months, whereas for the interval of up to 12 months, the prevalence increased to $57 \%$. 
Table 2 Crude and adjusted regression analysis of diagnostic time up to 3 months and independent variables in patients with rheumatoid arthritis in Blumenau, Santa Catarina, Brazil, 2014

\begin{tabular}{|c|c|c|c|c|c|c|}
\hline \multirow[t]{2}{*}{ Variables } & \multicolumn{3}{|c|}{ Crude analysis } & \multicolumn{3}{|c|}{ Adjusted analysis } \\
\hline & (PRc) & $\mathrm{Cl} 95 \%$ & $p$ & (PRa) & $\mathrm{Cl} 95 \%$ & $p$ \\
\hline \multicolumn{3}{|l|}{$\operatorname{Sex}(n=296)$} & 0,146 & & & $0,154^{* *}$ \\
\hline Male & 0,84 & $(0,6-1,0)$ & & 0,85 & $(0,6-1,0)$ & \\
\hline Female & 1 & & & 1 & & \\
\hline \multicolumn{3}{|l|}{ Age in years $(n=287)$} & 0,200 & & & $0,267^{* *}$ \\
\hline $20-39$ & 1 & & & 1 & & \\
\hline $40-59$ & 0,83 & $(0,6-1,0)$ & & 0,84 & $(0,6-1,0)$ & \\
\hline$\geq 60$ & 0,80 & $(0,6-1,0)$ & & 0,81 & $(0,6-1,0)$ & \\
\hline \multicolumn{3}{|l|}{ Education in completed years $(n=284)$} & $0,459^{*}$ & & & $0,314^{* *}$ \\
\hline $0-4$ & 0,93 & $(0,7-1,1)$ & & 0,90 & $(0,7-1,0)$ & \\
\hline $5-8$ & 1,08 & $(0,9-1,2)$ & & 1,07 & $(0,9-1,2)$ & \\
\hline$>9$ & 1 & & & 1 & & \\
\hline \multicolumn{3}{|c|}{ Current monthly personal income in minimum wages $(n=248)$} & $0,801^{*}$ & & & $0,622^{* *}$ \\
\hline Third tertile (higher) & 1 & & & 1 & & \\
\hline Second tertile & 1,01 & $(0,8-1,2)$ & & 1,01 & $(0,8-1,2)$ & \\
\hline First tertile (lower) & 0,97 & $(0,8-1,1)$ & & 0,95 & $(0,7-1,1)$ & \\
\hline \multicolumn{3}{|l|}{ Body mass index $\left(\mathrm{Kg} / \mathrm{m}^{2}\right)(n=285)$} & 0,010 & & & 0,031 \\
\hline$\leq 24,9$ & 1 & & & 1 & & \\
\hline $25-29,9$ & 1,18 & $(0,9-1,4)$ & & 1,16 & $(0,9-1,4)$ & \\
\hline$\geq 30$ & 1,26 & $(1,0-1,5)$ & & 1,23 & $(1,0-1,5)$ & \\
\hline \multicolumn{3}{|c|}{ Type of servicee in the last 12 months $(n=269)$} & 0,177 & & & $0,623^{* *}$ \\
\hline Public healthcare system & 0,87 & $(0,7-1,0)$ & & 0,95 & $(0,7-1,1)$ & \\
\hline Supplementary healthcare system & 0,95 & $(0,8-1,1)$ & & 0,96 & $(0,8-1,1)$ & \\
\hline Fee-for-service care & 1 & & & 1 & & \\
\hline \multicolumn{6}{|c|}{ Total number of consultations with a rheumatologist in the last 12 months $(n=281)$} & $0,163^{* *}$ \\
\hline $0-1$ & 0,86 & $(0,6-1,1)$ & & 0,85 & $(0,6-1,0)$ & \\
\hline $2-3$ & 1 & & & 1 & & \\
\hline$\geq 4$ & 0,89 & $(0,7-1,0)$ & & 0,89 & $(0,7-1,0)$ & \\
\hline \multicolumn{3}{|l|}{ Disease time in months $(n=235)$} & $0,247^{*}$ & & & $0,605^{* *}$ \\
\hline $0-24$ & 1 & & & 1 & & \\
\hline$>24$ & 1,16 & $(0,8-1,5)$ & & 1,07 & $(0,8-1,3)$ & \\
\hline \multicolumn{3}{|l|}{ Use of csDMARD $(n=296)$} & $0,383^{*}$ & & & $0,283^{* *}$ \\
\hline Yes & 1 & & & 1 & & \\
\hline No & 1,06 & $(0,9-1,2)$ & & 1,12 & $(0,9-1,3)$ & \\
\hline \multicolumn{3}{|l|}{ Use of TNFi (ADA + ETA+IFX) $(n=288)$} & $0,960^{*}$ & & & $0,277^{* *}$ \\
\hline Yes & 0,99 & $(0,8-1,1)$ & & 0,88 & $(0,7-1,0)$ & \\
\hline No & 1 & & & 1 & & \\
\hline \multicolumn{3}{|l|}{$\mathrm{HAQ}(\mathrm{n}=165)$} & $0,901^{*}$ & & & $0,587^{* *}$ \\
\hline 0-1 (mild) & 1 & & & 1 & & \\
\hline 1,1-2 (moderate) & 0,89 & $(0,7-1,1)$ & & 0,86 & $(0,6-1,1)$ & \\
\hline 2,1-3 (severe) & 1,01 & $(0,8-1,2)$ & & 0,92 & $(0,6-1,3)$ & \\
\hline
\end{tabular}


Table 2 Crude and adjusted regression analysis of diagnostic time up to 3 months and independent variables in patients with rheumatoid arthritis in Blumenau, Santa Catarina, Brazil, 2014 (Continued)

\begin{tabular}{|c|c|c|c|c|c|c|}
\hline \multirow[t]{2}{*}{ Variables } & \multicolumn{3}{|c|}{ Crude analysis } & \multicolumn{3}{|c|}{ Adjusted analysis } \\
\hline & (PRc) & Cl 95\% & p & (PRa) & $\mathrm{Cl} 95 \%$ & $p$ \\
\hline \multicolumn{3}{|c|}{ Presence of radiological changes (erosions) in hands $(n=237)$} & $0,814^{*}$ & & & $0,306^{* *}$ \\
\hline No & 1 & & & 1 & & \\
\hline Yes & 0,98 & $(0,8-1,1)$ & & 1,13 & $(0,8-1,4)$ & \\
\hline \multicolumn{2}{|l|}{ Current professional situation (237) } & & $0,324^{*}$ & & & $0,637^{* *}$ \\
\hline Working & 1 & & & 1 & & \\
\hline Health insurance & 0,99 & $(0,7-1,2)$ & & 0,99 & $(0,7-1,4)$ & \\
\hline Disability retirement & 0,94 & $(0,7-1,1)$ & & 0,89 & $(0,6-1,1)$ & \\
\hline Retirement for time of service & 0,91 & $(0,7-1,1)$ & & 0,95 & $(0,7-1,2)$ & \\
\hline
\end{tabular}

csDMARD conventional synthetic disease-modifying antirheumatic drugs, TNFi tumor necrosis factor inhibitors, ADA adalimumab, ETA etanercept, IFX infliximab, $H A Q$ health assessment questionnaire, $P R c$ crude prevalence ratio, $P R a$ adjusted prevalence ratio; $\mathrm{Cl} 95 \%$ : confidence interval of $95 \%$

* Value of $p>0,20$ excluded from the adjusted analysis. ${ }^{* *}$ Value of $p>0,05$ excluded of final model

In the adjusted analysis, the variables sex, age, total number of consultations, time of disease and current professional situation lost power of association with both diagnostic periods, excluded from the final model. The BMI remained in the final model in the two periods represented by the obesity category, respectively, with a prevalence of $23 \%$ and $107 \%$ higher in relation to the ideal weight patient. The variable education remained in the model for the diagnosis period up to 12 months, with $59 \%$ higher prevalence in the category of $0-4$ years of study. (Tables 2 and 3).

\section{Discussion}

The present study observed that the mean time from onset of symptoms to diagnosis was 28 months. The prevalence of the diagnosis of very early rheumatoid arthritis was $27.7 \%$, whereas in the late initial period it was $64.8 \%$. Although the majority of the patients received the diagnosis up to 12 months, the others presented a great diagnostic delay, which increased the mean time of diagnosis of the disease.

The research identified that the lower educational level of the patient was directly related to the diagnosis later than 12 months. Also, there was a progressive increase in the prevalence of obesity between the diagnostic periods.

Previous studies conducted in other Brazilian cities showed a diagnostic time of approximately 8 [17], 12 [18] and 39 months [9], showing that the present study is within the national intervals, and presented similarity to a study in Brasília, whose time was 27 months [19]. The international literature offers a variety of data, such as a mean time of 6 months in European countries [20], 30 months in Saudi Arabia [7] and up to 33 months in Colombia [21]. These data show that there are contributing factors for the diagnostic time that differ according to locality. The prevalence of patients diagnosed in the first 3 months of the symptoms is in line with both national (35.3\%) [17] and international data, which show values of $1-50 \%$ [22] and $32-38 \%$ [23]. The prevalence found in the period was found to be better than that found in Sri Lanka (0.7\%) [24], but worse than that found in Uruguay (45\%) [25] and Norway (50\%) [26].

Possible association factors with RA diagnosis time, including social and demographic profile, were analyzed. It was observed that the sex and age of the patients were not related to the dependent variables, as was found in studies carried out in Belgium [27], Norway [26] and England [28] and contrary to a Canadian study that states that women and younger individuals have less diagnostic time [29]. In the present study, patients with less years of study had a later diagnosis, this data contradicts Venezuelan and Canadian literature, where there was no association with this variable $[12,30]$. This may occur due to the possible relationship of lower education and income; and consequent greater use of the public health system, which generates more waiting for consultation with a specialist. In Blumenau, this waiting time for consultation is up to 2 months (unpublished data).

It is known that obesity is a frequent condition in patients with RA [31, 32]. According to the present study, when we compared patients with a later diagnosis in relation to the very early, they were more strongly associated with BMI. For the authors' knowledge, this is the first article to demonstrate this association and should be confirmed in the future research. As justification, it is suggested that patients with greater time to diagnosis have more difficulty controlling the disease and therefore use more drugs, such as glucocorticoid, which may influence the weight gain [33]. The result could also occur due to a more advanced disease, which leads to greater disability, favoring the sedentary lifestyle and increased BMI of the patient. 
Table 3 Crude and adjusted regression analysis of diagnostic time up to 12 months and independent variables in patients with rheumatoid arthritis in Blumenau, Santa Catarina, Brazil, 2014

\begin{tabular}{|c|c|c|c|c|c|c|}
\hline \multirow[t]{2}{*}{ Variables } & \multicolumn{3}{|c|}{ Crude analysis } & \multicolumn{2}{|c|}{ Adjusted analysis } & \multirow[b]{2}{*}{$p$} \\
\hline & (RPc) & $\mathrm{Cl} 95 \%$ & $p$ & (PRa) & $\mathrm{Cl} 95 \%$ & \\
\hline \multicolumn{3}{|l|}{$\operatorname{Sex}(n=296)$} & $0,704^{*}$ & & & $0,720^{* *}$ \\
\hline Male & 1,08 & $(0,7-1,6)$ & & 1,07 & $(0,7-1,6)$ & \\
\hline Female & 1 & & & 1 & & \\
\hline \multicolumn{3}{|l|}{ Age in years $(n=287)$} & $0,894^{*}$ & & & $0,920^{* *}$ \\
\hline $20-39$ & 1 & & & 1 & & \\
\hline $40-59$ & 0,91 & $(0,4-1,7)$ & & 0,91 & $(0,6-1,7)$ & \\
\hline$\geq 60$ & 0,96 & $(0,4-1,8)$ & & 0,95 & $(0,4-1,8)$ & \\
\hline \multicolumn{3}{|l|}{ Education in completed years $(n=284)$} & 0,094 & & & 0,041 \\
\hline $0-4$ & 1,37 & $(0,9-2,1)$ & & 1,59 & $(1,1-2,5)$ & \\
\hline $5-8$ & 1,20 & $(0,7-1,8)$ & & 1,29 & $(0,7-2,1)$ & \\
\hline$>9$ & 1 & & & 1 & & \\
\hline \multicolumn{3}{|c|}{ Current monthly personal income in minimum wages $(n=248)$} & $0,496^{*}$ & & & $0,741^{* *}$ \\
\hline Third tertile (higher) & 1 & & & 1 & & \\
\hline Second tertile & 0,96 & $(0,6-1,4)$ & & 0,91 & $(0,5-1,4)$ & \\
\hline First tertile (lower) & 1,11 & $(0,7-1,6)$ & & 1,07 & $(0,7-1,6)$ & \\
\hline \multicolumn{3}{|l|}{ Body mass index $\left(\mathrm{Kg} / \mathrm{m}^{2}\right)(n=285)$} & 0,001 & & & 0,001 \\
\hline$\leq 24,9$ & 1 & & & 1 & & \\
\hline $25-29,9$ & 1,55 & $(1,0-2,3)$ & & 1,62 & $(1,0-2,4)$ & \\
\hline$\geq 30$ & 1,97 & $(1,2-2,9)$ & & 2,07 & $(1,3-3,1)$ & \\
\hline \multicolumn{3}{|c|}{ Type of servicee in the last 12 months $(n=269)$} & $0,515^{*}$ & & & $0,997^{* *}$ \\
\hline Public healthcare system & 0,86 & $(0,5-1,3)$ & & 1,01 & $(0,6-1,6)$ & \\
\hline Supplementary healthcare system & 0,97 & $(0,6-1,4)$ & & 0,90 & $(0,5-1,4)$ & \\
\hline Fee-for-service care & 1 & & & 1 & & \\
\hline \multicolumn{6}{|c|}{ Total number of consultations with a rheumatologist in the last 12 months $(n=281)$} & $0,223^{* *}$ \\
\hline $0-1$ & 0,75 & $(0,4-1,2)$ & & 0,79 & $(0,4-1,3)$ & \\
\hline $2-3$ & 1 & & & 1 & & \\
\hline$\geq 4$ & 0,72 & $(0,5-1,0)$ & & 0,79 & $(0,5-1,1)$ & \\
\hline \multicolumn{3}{|l|}{ Disease time in months ( $n=235$ ) } & 0,134 & & & $0,115^{* *}$ \\
\hline $0-24$ & 1 & & & 1 & & \\
\hline$>24$ & 1,57 & $(0,8-2,8)$ & & 1,76 & $(0,8-3,5)$ & \\
\hline \multicolumn{3}{|l|}{ Use of csDMARD $(n=296)$} & $0,994^{*}$ & & & $0,744^{* *}$ \\
\hline Yes & 1 & & & 1 & & \\
\hline No & 0,99 & $(0,7-1,3)$ & & 1,08 & $(0,6-1,7)$ & \\
\hline \multicolumn{3}{|l|}{ Use of TNFi (ADA + ETA+IFX) $(n=288)$} & $0,588^{*}$ & & & $0,217^{* *}$ \\
\hline Yes & 0,91 & $(0,6-1,2)$ & & 0,75 & $(0,4-1,1)$ & \\
\hline No & 1 & & & 1 & & \\
\hline \multicolumn{3}{|l|}{$\mathrm{HAQ}(n=165)$} & $0,227^{*}$ & & & $0,867^{* *}$ \\
\hline 0-1 (mild) & 1 & & & 1 & & \\
\hline 1,1-2 (moderate) & 0,68 & $(0,4-1,1)$ & & 0,78 & $(0,6-1,1)$ & \\
\hline 2,1-3 (severe) & 0,76 & $(0,4-1,2)$ & & 0,82 & $(0,6-1,3)$ & \\
\hline
\end{tabular}


Table 3 Crude and adjusted regression analysis of diagnostic time up to 12 months and independent variables in patients with rheumatoid arthritis in Blumenau, Santa Catarina, Brazil, 2014 (Continued)

\begin{tabular}{|c|c|c|c|c|c|c|}
\hline \multirow[t]{2}{*}{ Variables } & \multicolumn{3}{|c|}{ Crude analysis } & \multicolumn{2}{|c|}{ Adjusted analysis } & \multirow[b]{2}{*}{$p$} \\
\hline & (RPc) & $\mathrm{Cl} 95 \%$ & $p$ & (PRa) & $\mathrm{Cl} 95 \%$ & \\
\hline \multicolumn{3}{|c|}{ Presence of radiological changes (erosions) in hands $(n=237)$} & $0,668^{*}$ & & & $0,877^{* *}$ \\
\hline No & 1 & & & 1 & & \\
\hline Yes & 1,08 & $(0,7-1,5)$ & & 1,03 & $(0,6-1,6)$ & \\
\hline \multicolumn{2}{|l|}{ Current professional situation (237) } & & 0,125 & & & $0,088^{* *}$ \\
\hline Working & 1 & & & 1 & & \\
\hline Health insurance & 1,11 & $(0,6-1,8)$ & & 1,34 & $(0,8-2,1)$ & \\
\hline Disability retirement & 0,99 & $(0,6-1,4)$ & & 0,85 & $(0,5-1,3)$ & \\
\hline Retirement for time of service & 0,67 & $(0,4-1,1)$ & & 0,68 & $(0,4-1,1)$ & \\
\hline
\end{tabular}

csDMARD conventional synthetic disease-modifying antirheumatic drugs, TNFi tumor necrosis factor inhibitors, ADA adalimumab, ETA etanercept, IFX infliximab, $H A Q$ health assessment questionnaire, PRc crude prevalence ratio; PRa: adjusted prevalence ratio; $\mathrm{Cl} 95 \%$ : confidence interval of $95 \%$

* Value of $p>0,20$ excluded from the adjusted analysis. ${ }^{* *}$ Value of $p>0,05$ excluded of final model

As for the time of disease, an average of 126 months was found, higher than that found in another Brazilian study that was 92 months [34]. There was no statistical association between diagnosis time and disease time, but patients with a recent disease had an earlier diagnosis, whereas patients with a longer disease period ( $>2$ years) had a later diagnosis, as observed in international studies $[22,35]$.

The symptoms of RA can be initially attenuated with symptomatic drugs, however, the specific treatment for the disease is done with cs DMARD and, when they do not achieve adequate control of disease activity, TNFi drugs, which are bDMARD medications [36, 37]. In this study, there was no significant association in the use of cs DMARD and / or TNFi and time to diagnosis. Despite this, it was possible to observe that patients diagnosed up to 3 months would have less need to use cs DMARD when compared to those diagnosed up to 12 months. This finding was also found in the Leiden cohort (Netherlands), stating that there was a higher remission rate without the use of cs DMARD in patients evaluated within 3 months [5]. Regarding the use of TNFi, in earlier diagnosis, there would be less need to use, as found in an Italian study [22].

In the present study, patients had an average of 3.4 consultations in the last year with a rheumatologist, similar to the national data [16, 38]. No statistical association was found regarding the number of consultations with rheumatologists in the last year and the diagnostic interval. However, it was observed that when the diagnosis was made within 3 months, patients consumed fewer visits in the last year compared to those diagnosed within 12 months. This is probably due to better control of the disease when diagnosed earlier, requiring fewer consultations during the year.

It was seen that as the time to diagnosis increased, the prevalence of patients with an intermediate or worse HAQ also increased, although there was no association with the dependent variable. A study conducted between 2007 and 2009 with 1795 patients also showed that individuals diagnosed earlier were able to maintain lower values of HAQ in their follow-up [22]. Non-association could be attributed to a smaller sample of patients when compared to the other variables.

The presence of radiological alterations in hands was observed in the majority of the patients, a result that may have occurred because most of the patients in the sample had more disease time and therefore the availability of resources was more precarious than the ones we have currently, and could favor greater joint damage. In addition, it was initially observed that the later the diagnosis, the greater the prevalence of erosions in the patients hands, as evidenced in a work performed with patients in the state of São Paulo [39].

The results showed a trend that the later the diagnosis, the lower the prevalence of patients being able to retire due to length of service. Brazilian literature confirms this information when it cites that the delay in diagnosis increases the individual's incapacity to work [9]. Regarding the type of care, most of the patients in the sample used the SUS in the last year. In spite of this, there was a tendency of a higher prevalence of the diagnosis of very early RA in the private service when compared to SUS of the order of $13 \%$. As justification, it is assumed that individuals diagnosed earlier would have a higher economic level to obtain faster service.

Some limitations should be considered in this research. The transversal design of the study makes it impossible to determine cause and effect between the exploratory variables and the outcome. Based on the obtained results, the possibility of characteristic reverse causality in cross-sectional studies is highlighted. Other factors to take into account concern the possibility of memory bias in collecting some information attenuated by the common feature of RA being a chronic injury. The agreement between the answers of the first and the second questionnaire including the dependent variable was $82 \%$ (unpublished data). 


\section{Conclusion}

Therefore, this research reinforces the need to know the factors that may delay the earlier diagnosis of RA; and thus decrease the chances of the best results for the patient. It was evidenced that the socioeconomic factor, lower education, was associated with a later initial diagnosis. As a result of the longer diagnosis time there was a progressive increase in the prevalence of obesity among patients. We suggest that more studies be carried out regarding this theme in order to know the local realities, in order to speed up the access of care of the individuals affected by the disease, reinforcing the importance of the early diagnosis.

\section{Abbreviatons \\ bDMARD: Biological disease-modifying antirheumatic drugs; BMI: body mass index; CsDMARD: Conventional synthetic disease-modifying antirheumatic drugs; FURB: Blumenau Regional University Foundation; HAQ: Health Assessment Questionnaire; LERA: Late Early Rheumatoid Arthritis; MS: Ministry of Health; PR: Prevalence ratios; RA: Rheumatoid arthritis (RA); SD: Standard deviation; SUS: Unified Health System; TNFi: Tumor necrosis factor inhibitors; USP: University of São Paulo; VERA: Very Early Rheumatoid Arthritis; WHO: World Health Organization}

\section{Availability of data and materials}

All data generated and analysed during this article are part of the project: Cohort study of patients with rheumatoid arthrtis of the municipality of Blumenau.

\section{Authors' contributions}

RKSG contributed to elaboration, literature review, statistical analysis and article writing. ACL e LSL contributed to writing and literature review. All approved final version for submission in journal.

\section{Ethics approval and consent to participate}

Submitted to the research ethics committee of the University of São Paulo (USP) and Blumenau Regional University Foundation (FURB) (protocol n.339 / 13 and 133/12, respectively).

\section{Consent for publication}

Not applicable.

\section{Competing interests}

The authors declare that they have no competing interests.

\section{Publisher's Note}

Springer Nature remains neutral with regard to jurisdictional claims in published maps and institutional affiliations.

\section{Author details}

${ }^{1}$ Specialty Center of the City of Blumenau, Blumenau, Santa Catarina State (SC), Brazil. ${ }^{2}$ Specialty Center of the City of Brusque, Brusque, SC, Brazil. ${ }^{3}$ School of Medicine, Regional University of Blumenau (Universidade Regional de Blumenau - FURB), Blumenau, Brazil. ${ }^{4}$ Centro de Referência Policlínica Lindolf Bell, Rua: Dois de Setembro, 1234 - Itoupava Norte, $3^{\circ}$ andar, sala 1. CEP, Blumenau, SC 89052-003, Brazil.

Received: 20 March 2018 Accepted: 3 October 2018

Published online: 22 October 2018

\section{References}

1. American College of Rheumatology Subcommitte on Rheumatoid Arthritis Guidelines. Guidelines for the management of rheumatoid arthritis. Arthritis Rheumatology. 2002;46:328-46.

2. Da Mota Licia Maria Henrique, Laurindo leda Maria Magalhães e Dos Santos Neto Leopoldo Luiz. Artrite reumatoide inicial: conceitos. Rev Assoc Med Bras 2010; 56(2):227-229.
3. Da Henrique MLM, Alfonso CB, Viegas BC, Alves PI, Stange R-FL, Barros BM, et al. Guidelines for the diagnosis of rheumatoid arthritis. Rev Bras Reumatol. 2013;53(2):141-57.

4. Cheung PP, Dougados M, Andre V, Balandraud N, Chales G, Chary-Valckenaere I, et al. Improving agreement in assessment of synovitis in rheumatoid arthritis. Joint Bone Spine. 2013:80(2):155-9.

5. der Linden Michael V, Saskia le C, Karim R, der Woude Diane V, Rachel K, Tom H, der Helm-van Mil Annette V. Long-term impact of delay in assessment of patients with early arthritis. Arthritis Rheumatology. 2010; 62(12):3537-46.

6. Nell VP, Machold KP, Eberl G, Stamm TA, Uffmann M, Smolen JS. Benefit of very early referral and very early therapy with diseasemodifying antirheumatic drugs in patients with early rheumatoid arthritis. Oxford J. 2004;43:906-14.

7. Hussain W, Noorwali A, Janoudi N, Baamer M, Kebbi L, Mansafi H, et al. From symptoms to diagnosis: an observational study of the journey of rheumatoid arthritis patients in Saudi Arabia. Oman Med J. 2016;31(1):29-34

8. Kiely P, Williams R, Walsh D, Young A. Contemporary patterns of care and disease activity outcome in early rheumatoid arthritis: the ERAN cohort. Rheumatology. 2009;48:57-60.

9. Melo V, Aguiar F, Baleroni T, Novaes G. Análise temporal entre início dos sintomas, avaliação reumatológica e tratamento com drogas modificadoras de doença em pacientes com artrite reumatoide. Ver Fac Ciênc Méd Sorocaba. 2008;10(2):12-5.

10. Combe B, Landewe R, Lukas C, Bolosiu HD, Breedveld F, Dougados M, et al. EULAR recommendations for the management of early arthritis: report of a task force of the European Standing Committee for International Clinical Studies Including Therapeutics (ESCISIT). Ann Rheum Dis. 2007;66(1):34-5.

11. Feldman DE, Bernatsky S, Haggerty J, Leffondré $K$, Tousignant $P$, Leffondré $K$, et al. Delay in consultation with specialists for persons with suspected new-onset rheumatoid arthritis: a population based study. Arthritis Rheum. 2007;57:1419-25.

12. Rodríguez-Polanco E, Al Snih S, Kuo YF, Millán A, Rodríguez MA Lag time between onset of symptoms and diagnosis in Venezuelan patients with rheumatoid arthritis. Rheumatol Int 2011; 31(5):657-65.

13. Da Mota LM, Cruz BA, Brenol CV, Pereira IA, Fronza LS, Bertolo MB, et al. Consensus of the Brazilian Society of Rheumatology for diagnosis and early assessment of rheumatoid arthritis. Rev Bras Reumatol. 2011;51(3):199-219.

14. James F, Patricia S, Halsted KGH. Measurement of patient outcome in arthritis. Arthritis Rheum. 1980;23:137-45.

15. Ministério da Saúde. Portaria SCTIE no 66, de 6 de novembro de 2006. Protocolo Clínico e Diretrizes Terapêuticas - artrite reumatoide. Diário Oficial da União 2006

16. Bagatini BF, Raquel BC, Estima MAC, Nair LS, Rocha FM. Estudo de custoanálise do tratamento da artrite reumatoide grave em um município do Sul do Brasil. Cad Saúde Pública. 2013;29(1):81-91.

17. Da Mota Licia M, leda L, Leopoldo N. Características demográficas e clínicas de uma coorte de pacientes de artrite reumatoide inicial. Rev Bras Reumatol. 2010;50(3):235-48.

18. David Juliano M, Mattei Rodrigo A, Mauad Juliana L, Almeida Lauren G, Nogueira Marcio A, Poliana M, et al. Estudo clínico e laboratorial de pacientes com artrite reumatoide diagnosticados em serviço de reumatologia em Cascavel, PR, Brasil. Rev Bras Reumatol. 2013;53(1):57-65.

19. Cunha BM, de Oliveira SB, dos Santos-Neto LL. Coorte Sarar: atividade de doença, capacidade funcional e dano radiológico em pacientes com artrite reumatoide submetidos à artroplastia total de quadril e joelho. Rev Bras Reumatol. 2015;55(5):420-6.

20. Karin R, Rebecca S, Kanta K, Andrew F, Jacqueline D, Hans B, et al. Delays in assessment of patients with rheumatoid arthritis: variations across Europe. Ann Rheum Dis. 2011;70:1822-5

21. Ruiz O, Salazar JC, Londoño PJ, Saiibi DL, Molina JF, Santos P, et al. Cambio en la capacidad funcional, calidad de vida y actividad de la enfermedad, en un grupo de pacientes colombianos con artritis reumatoide refractaria al tratamiento convencional, que recibieron terapia con infliximab como medicamento de rescate. Revista Med. 2009;17(1):40-9.

22. Elisa G, Fausto S, Laura BS, Alessandro C, Francesca B-P, Roberto C, et al. Very early rheumatoid arthtitis as a predictor of remission: a multicentre real life prospective stydy. Ann Rheum Dis. 2013;72:858-62.

23. Jessica N, Elisabeth B, Floris G, Cornelia A, Tom H, Marcel P, et al. Improved early identification of arthritis: evaluating the efficacy of early Artrhitis recognition clinics. Ann Rheum Dis. 2013;72:1295-301. 
24. Atukaorala I, Wljewickrama P, Gunawardena MPH, Atukorala K, Weerathunga D, Dharmasena $\mathrm{D}$. The community prevalence of early rheumatoid arthritis and health seeking behavior of affected individuals. Int J Epidemiol. 2015;44(1): 2016-207.

25. Palleiro D. Diagnostic delay in rheumatoid arthritis. J Clin Rheumatol. 2006;12:41.

26. Palm O, Purinszky E. Women with early rheumatoid arthritis are referred later than men. Ann Rheum Dis. 2005;64:1227-8.

27. De Cock D, Meyfroidt S, Joly J, Van Der Elst K, Westhovens R, Verschueren P. A detailed analysis of treatment delay from the onset of symptons in early rheumatoid arthritis patients. Scand J Rheumatol 2014;43:1-8.

28. Kumar K, Daley DM, Carruthers D, Situnayake C, Gordon K, Grindulis CD, et al. Delay in presentation to primary care physicians is the main reason why patients with rheumatoid arthritis are seen later by rheumatologists. Rheumatology. 2007:46:1438-40.

29. Feldman Debbie E, Sasha B, Jeannie H, Karen L, Pierre T, Yves R, et al. Delay in consultation with specialists for persons with suspected new-onset rheumatoid arthritis: a population-based study. Arthritis Care \& Research. 2007;57(8):1419-25.

30. Cheryl B, Juan X, Pope Janet E, Gilles B, Carol H, Boulos H, et al. Factors associated with time to diagnosis in early rheumatoid arthritis. Rheumatol Int. 2014;34:85-92.

31. Junior RSD, Ferraz AL, Oesterreich AS, Schmitz WO, Shinzato MM. Caracterização de pacientes com artrite reumatoide quanto a fatores de risco para doenças vasculares cardíacas no Mato Grosso do Sul. Rev Bras Reumatol. 2015;55(6):493-500.

32. Rachel Z, Marcia D, Thelma S. Perfil nutricional na artrite reumatoide. Rev Bras Reumatol. 2013;54(1):68-72.

33. Michael G, Joshua B. The obesity epidemic and consequences for rheumatoid arthritis. Curr Rheumatol Rep. 2016;18(1):6.

34. Almeida Maria do Socorro TM, Almeida João Vicente M, Bertolo Manuel B. Características demográficas e clínicas de pacientes com artrite reumatoide no Piauí, Brasil - avaliação de 98 pacientes. Rev Bras Reumatol. 2014;54(5):360-5.

35. Jennifer A, George W, Verhoeven Arco C, Felson David T. Factors predicting response to treatment in rheumatoid arthritis: the importance of disease duration. Arthritis \& Rheumatism. 2000;43:22-9.

36. Jasvinder S, Kenneth S, Louis B Jr, Elie A, Raveendhara B, Matthew S, et al. 2015 American College of Rheumatology Guideline for the treatment of rheumatoid arthritis. Arthritis Care Res. 2015;67(10):1335-486.

37. Monika S, John W, David S, Angela Z, Pamela R, Robert L, et al. Economic aspects of treatment options in rheumatoid arthritis: a systematic literature review informing the EULAR recommendations for the management of rheumatoid arthritis. Ann Rheum Dis. 2010;69:996--1004.

38. Vaz Andrey E, Faria Wilmar A Jr, Lazarski Cristina FS, Do Carmo Humberto Franco, Da Rocha Hermínio Maurício. Perfil epidemiológico e clínico de pacientes portadores de artrite reumatóide em um hospital escola de medicina em Goiânia, Goiás, Brasil. Medicina (Ribeirão Preto) 2013;46(2):141-153.

39. Louzada-Junior P, Souza BDB, Toledo RA, Ciconelli RM. Análise descritiva das características demográficas e clínicas de pacientes com artrite reumatoide no estado de São Paulo, Brasil. Rev Bras Reumatol. 2007;47(2):84-90.

Ready to submit your research? Choose BMC and benefit from:

- fast, convenient online submission

- thorough peer review by experienced researchers in your field

- rapid publication on acceptance

- support for research data, including large and complex data types

- gold Open Access which fosters wider collaboration and increased citations

- maximum visibility for your research: over $100 \mathrm{M}$ website views per year

At BMC, research is always in progress.

Learn more biomedcentral.com/submissions 